THE BOLSHEVIK PARTY IN REVOLUTION 


\section{THE BOLSHEVIK PARTY IN REVOLUTION}

\section{A Study in Organisational Change 1917-1923}

ROBERT SERVICE

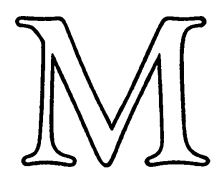


() Robert Service 1979

Softcover reprint of the hardcover 1st edition 1979

All rights reserved. No part of this publication may be reproduced or transmitted, in any form or by any means, without permission

First published 1979 by THE MACMILLAN PRESS LTD

London and Basingstoke

Associated companies in Delhi

Dublin Hong Kong Johannesburg Lagos

Melbourne New York Singapore Tokyo

Photoset in Great Britain by

Bristol Typesetting Co Ltd, Bristol

\section{British Library Cataloguing in Publication Data}

\section{Service, Robert}

The Bolshevik party in revolution

1. RossiY̌skaía sotsial-demokraticheskaía rabochaía (Bol'sheviki)-History

I. Title

$329.9^{\prime} 47$

HN6598.S6

ISBN 978-1-349-03773-5 ISBN 978-1-349-03771-1 (eBook)

DOI 10.1007/978-1-349-03771-1

This book is sold subject to the standard conditions of the Net Book Agreement 


\section{TO MY PARENTS}




\section{Contents}

Acknowledgements viii

Introduction 1

1 The Tides of Revolution 11 (1861-1917)

2 The Bolsheviks Advance 37 (February 1917-October 1917)

3 Victory in Defeat (November 1917-May 1918)

4 The Alarm is Sounded (June 1918-March 1919)

5 The Battle is Won (April 1919-March 1920)

6 Defeat in Victory (April 1920-March 1921)

7 The Bolsheviks Retreat (March 1921-December 1922)

8 The Winds of Bureaucracy (January 1923-January 1924)

Conclusions 


\section{Acknowledgements}

The relief felt in dispatching this manuscript to the publishers is equalled only by the sense of gratitude owed to the friends who have helped me to reach such a position. The Russian Studies Department at Keele is an academic microcosm of peaceful coexistence. Genia Lampert, the late Katia Lampert, Joe Andrew, Roger Bartlett, Chris Pike and Valentina Polukhina have offered encouragement and advice on a broad spectrum of matters Russian and Soviet. Joe and Roger took comradely solidarity to the point of reading the draft chapters. I should also like to thank Charles Duval, Roger Pethybridge and Rick Twyman for their assistance in tackling particular problems which would otherwise have eluded me. And, collectively, the delegates to the Fourth Conference of the Russian Revolution Study Group in January of this year provoked a number of last-minute reformulations. Peter Frank of Essex University has over the years lent his wealth of expertise, energy and enthusiasm to this project. And Adele Biagi, my wife, has edited the book since its first draft, purging its pages of the more horrific (and more ludicrous) excesses of historiographical and typographical deviation.

All remaining distortions and falsifications are my own.

Keele

R.J.S.

Easter Saturday 1978 